\title{
PENGARUH VARIASI PUTARAN MESIN TERHADAP DAYA PADA ENGINE CUMMINS KTTA 38 C
}

\author{
Purwo Yulianto ${ }^{1}$, Arief Muliawan ${ }^{2}$ \\ ${ }^{1}$ Teknik Mesin, Universitas Trunajaya Bontang, e-mail: purwoyuli@ymail.com \\ ${ }^{2}$ Teknik Elektro, Sekolah Tinggi Teknologi Bontang
}

Diterima: 13 Januari 2016. Disetujui: 5 April 2016. Dipublikasikan: April 2016

\begin{abstract}
This study is about the effect of variations in engine rotation against the power of the engine Cummins KTTA 38 C used in loading tool for the coal mining that Komatsu PC 3000. This research was conducted at PT. Altrak 1978 Bontang which is a company engaged in the service and sales of heavy equipment. The purpose of this research is to know how to determine the engine speed of the engine power in accordance with Cummins KTTA 38C and how the influence of rotation on the power. The study was conducted on the engine general overhaul is carried out in November 2015 through January 2016. Testing of the engine is done by using test equipment dynotest is to get the engine speed and power that can be measured on a test device. The research showed that the engine Cummins KTTA 38 C to determine the engine speed to the appropriate power is round $1501 \mathrm{rpm}$ power of $46 \mathrm{HP}$, round of $1603 \mathrm{rpm}$ the power of $1178 \mathrm{HP}$, round of $1706 \mathrm{rpm}$ the power of $1253 \mathrm{HP}$, round of $1801 \mathrm{rpm}$ the power of $1324 \mathrm{HP}, 1910 \mathrm{rpm}$ rotation power of $46 \mathrm{HP}$. And the influence of the rotation Engine power is any change in engine speed that occurs can affect the value of the power produced by the engine itself.
\end{abstract}

\begin{abstract}
Abstrak: Penelitian ini merupakan telaah pengaruh variasi putaran mesin terhadap daya pada engine cummins KTTA $38 \mathrm{C}$ yang dipakai pada alat loading untuk pertambangan batubara yaitu Komatsu PC 3000. Penelitian ini dilakukan di PT. Altrak 1978 Bontang yang merupakan perusahaan bergerak di bidang jasa dan penjualan alat berat. Tujuan dari penelitian ini adalah untuk mengetahui bagaimana menentukan putaran engine terhadap daya yang sesuai dengan engine cummins KTTA 38C dan bagaimana pengaruh putarannya terhadap daya. Penelitian telah dilakukan general overhaul pada engine yaitu pada bulan November 2015 sampai Januari 2016. Pengujian engine dilakukan dengan menggunakan alat uji dynotest adalah untuk mendapatkan hasil putaran engine dan daya yang dapat terukur pada alat uji. Dari penelitian didapatkanhasil bahwa pada engine cummins KTTA $38 \mathrm{C}$ untuk menentukan putaran engine terhadap daya yang sesuai adalah pada putaran $1501 \mathrm{rpm}$ daya sebesar $46 \mathrm{HP}$, putaran $1603 \mathrm{rpm}$ daya sebesar $1178 \mathrm{HP}$, putaran $1706 \mathrm{rpm}$ daya sebesar $1253 \mathrm{HP}$, putaran $1801 \mathrm{rpm}$ daya sebesar $1324 \mathrm{HP}$, putaran $1910 \mathrm{rpm}$ daya sebesar 46 HP.Dan pengaruh putaran Engine terhadap daya adalah tiap perubahan putaran engine yang terjadi dapat mempengaruhi nilai daya yang di hasilkan oleh engine itu sendiri.
\end{abstract}

Kata kunci: rpm, daya engine, dynotest.

(C) 2016 Pendidikan Fisika FTK IAIN Raden Intan Lampung

\section{PENDAHULUAN}

Semakin meningkatnya pertumuhan ekonomi suatu Negara akan semakin tinggi pula kebutuhan akan energi,dimana energi tersebut di peroleh dari alam kita yang kaya akan sumber daya alamnya. Salah satu sumber daya alam yang kita miliki ialah batubara.Karena kebutuhan energi inilah banyak perusahaanperusahaan yang bergerak di bidang pertambangan.Produksi suatu penambangan batubara sangat ditentukan dari produktifitas alat-alat tambang seperti excavator, dump truck, dozer, grader,generator sets dan lain sebagainya(Clark, 1998). Dalam hal tersebut Cummins memproduksi engine untuk menyediakantenaga yang dibutuhkan untuk menggerakan alat-alat tambang tersebut. Seri engine cummins untuk tipe K antara lain adalah K19, K38 dan K50. TTA menunjukkan sistem pemasukan udara ke dalam ruang bakar yaitu double stage Turbocharger Aftercooler. Diantara banyaknya seri engine cummis yang diproduksi salah satunya adalah engine Cummins KTTA 38 $\mathrm{C}$ yang banyak diaplikasikan pada alat 
tambang dan generator sets. Engine yang telah mencapai jam kerja 12.000 jam dapat juga mengalami penurunan daya engine yang dapat diketahui dari putaran engine itu sendiri. Daya yang dikeluarkan engine akan mempengaruhi putaran engine. Yang mana putaran engine terhadap daya tidak sesuai dengan spesifikasi yang telah di tentukan oleh pabrikan engine cummins maka dapat dikatakan mengalami penurunan daya.

Putaran mesin yang sama dengan tingkat turbocharger berbeda mampu menghasilkan perfomansi daya yang berbeda. (Purnama, S. 2015). Fernandez menyatakan putaran mesin berpengaruh signifikan terhadap emisi gas buang, dimana kecenderungannya semakin tinggi putaran mesin maka emisi gas buang semakin menurun. (Fernandez, 2009)

Berkaitan dengan penjelasan tersebut diatas penulis tertarik untuk mengadakan penelitian dengan judul "Pengaruh Variasi Putaran Mesin Terhadap Daya Pada Engine Cummins KTTA 38 C".

\section{LANDASAN TEORI Pengertian Engine}

Engine secara umum didefinisikan sebagai penggerak, atau dengan kata lain motor bakar. Motor adalah suatu perangkat yang terdapat pada suatu benda yang bergerak berputar dan menghasilkan tenaga daripada engine itu sendiri. Sedangkan pengertian motor bakar adalah suatu mesin kalor dimana tenaga atau energi dari hasil pembakaran bahan bakar didalam silinder akan diubah menjadi energi mekanik.

\section{Prinsip Dasar Mesin Diesel}

Mesin diesel di kategorikan dalam motor bakar torak dan mesin pembakaran dalam (internal combustion engine). Prinsip kerja mesin diesel adalah merubah energi kimia menjadi energi mekanis. Energi kimia di dapatkan melalui proses reaksi kimia yaitu pembakaran dari bahan bakar (solar) dan oksidiser (udara) di dalam silinder (ruang bakar). Pembakaran pada mesin diesel terjadi karena kenaikan temperatur campuran udara dan bahan bakar akibat kompresi torak hinga mencapai temperatur nyala.

Mesin diesel adalah motor bakar torak yang proses penyalaannya bukan dengan loncatan bunga api listrik. Hanya udara yang masuk ke dalam silinder dalam langkah isap (Daryanto, 2004). Pada saat langkah kompressi, sebelum torak mencapai TMA (Titik Mati Atas) bahan bakar disemprotkan kedalam silinder dalam bentuk kabut. Proses penyalaan untuk pembakaran pun terjadi, pada saat udara di dalam silinder sudah bertemperatur tinggi. Syarat terjadinya pembakaran yaitu ada 3 unsur,yakni: ada udara,ada bahan bakar dan adanya panas.

Persyaratan ini dapat dipenuhi apabila digunakan perbandingan kompresi yang cukup tinggi berkisar 12-25, maka tekanan udara yang di kompressikan akan mencapai $26-40 \mathrm{~kg} / \mathrm{cm}^{2}$ dan suhunya mencapai $500-700^{\circ} \mathrm{C}$.

\section{Syarat-Syarat Terjadinya Pembakaran Pada Engine Cummins}

Unsur-unsur yang diperlukan agar terjadi pembakaran didalam silinder engine diesel cummins adalah harus ada bahan bakar, udara, panas, dan ruang bakar.

1. Bahan Bakar

Untuk engine diesel cummins ditentukan bahwa bahan bakar yang digunakan haruslah bahan bakar diesel no.2. Spesifikasinya dapat dilihat didalam buku operation and maintenance manual. Bahan bakar diesel ini mempunyai berat jenis $0.8389 \mathrm{~kg} / \mathrm{ltr}$ dan nilai kalorinya adalah $10.220 \mathrm{kcal} / \mathrm{kg}$. Nilai kalor ini dikenal sebagai lowest calorificvalue (LCV).

\section{Udara}

Jumlah udara yang masuk kedalam ruang bakar harus seimbang dengan bahan bahan bakar yang dibakar guna 
mendapatkan daya engine yang sesuai. Untuk itu digunakan turbocharger yang dapat menyesuaikan pemasukan udara. Perbandingan ideal untuk pembakaran yang baik antara udara dan bahan bakar adalah 20:1.

3. Panas

Pada panas tertentu bahan bakar diesel akan terbakar sendiri. Kenyataan ini jugalah yang menjadi dasar untuk pembakaran bahan bakar didalam silinder engine diesel cummins. Panas ini diperoleh dengan cara memampatkan udara didalam ruang bakar. Dengan tekanan udara kompresi sebesar kurang lebih $30 \mathrm{~kg} / \mathrm{cm}^{2}$ akan dicapai suhu minimum untuk pembakaran yaitu kurang lebih 550 derajad celcius.

4. Ruang Bakar

Agar pemakaran dapat berguna maka diperlukan ruang bakar yang sesuai.
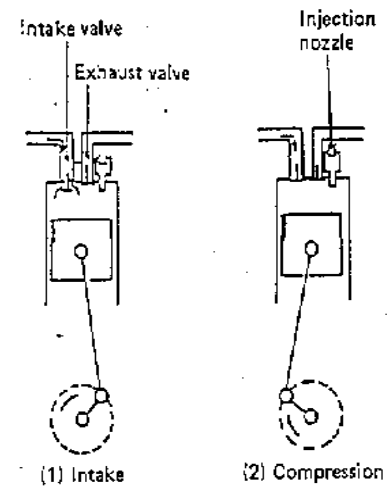

Gambar 1. Prinsip Kerja Motor Diesel 4 Langkah(Sumber gambar: mechanic development PT.Pama Persada Nusantara,2004)

Motor diesel 4 langkah adalah motor diesel yang setiap satu siklus pembakaran memerlukan empat kali gerakan naik turun torak atau dua kali putaran poros engkol. Siklus ini sama dengan mesin bensin 4 langkah, adapun proses siklus pembakaran atau langkah kerja pada motor diesel 4 langkah adalah sebagai berikut:

a. Langkah hisap (intake stroke)

Piston bergerak dari Titik Mati Atas (TMA) ke Titik Mati Bawah (TMB). Intake valve terbuka dan exhaust valve tertutup, udara murni masuk ke dalam silinder melalui intake valve.
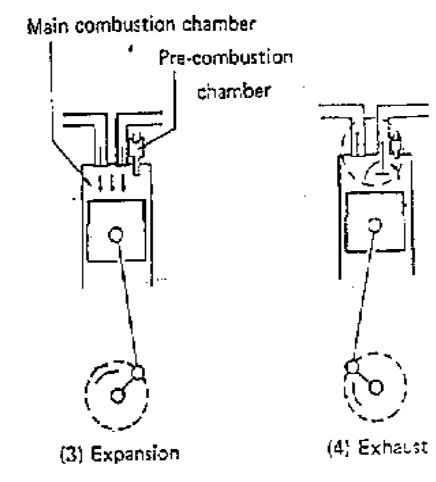

Besar ruang bakar diukur dalam satuan isinya sedangkan bentuknya dibuat sedemikian rupa dengan tujuan agar bahan bakar tersebut dapat terbakar dengan sempurna. Ruang bakar dibatasi oleh cylinder head,cylinder linier, dan permukaan atas piston. Semakin besar ruang bakar semakin besar pula daya yang dapat dihasilkan oleh engine, karena bahan bakar yang dibakar lebih banyak jumlahnya.

\section{Jenis Mesin Diesel}

Berdasarkan siklus kerjanya motor bakar diesel dibagi menjadi 2 macam yaitu motor diesel 4 langkah dan motor diesel 2 langkah. Berikut penjelasan mengenai motor diesel 4 langkah dan 2 langkah.

1. Motor diesel 4 langkah

\section{b. Langkah kompresi (Compression stroke)}

Udara yang berada di dalam silinder dimampatkan oleh piston yang bergerak dari Titik Mati Bawah (TMB) ke Titik Mati Atas (TMA), dimana kedua valve intake dan exhaust tertutup. Selama langkah ini tekanan naik $30-40 \mathrm{~kg} / \mathrm{cm} 2$ dan temperatur udara naik 400 - 500 derajat celcius.

c. Langkah Kerja (power stroke).

Pada langkah ini, intake valve dan exhaust valve masih dalam keadaan tertutup, partikel-partikel bahan bakar yang disemprotkan oleh nozzle akan 
bercampur dengan udara yang bertekanan dan suhu tinggi, sehingga terjadilah pembakaran yang menghasilkan tekanan dan suhu tinggi. Sehingga, tekanan naik dan temperatur menjadi 600-900 derajat celcius.Pada langkah ini piston bergerak dari Titik Mati Atas (TMA) menuju Titik Mati Bawah (TMB).

d. Langkah buang (exhaust stroke).

Exhaust valve terbuka sesaat sebelum piston mencapai titik mati bawah sehingga gas pembakaran mulai keluar.
Piston bergerak dari TMB menuju TMA yaitu mendorong gas buang keluar seluruhnya menuju muffler dan keluar menuju udara bebas.

Kesimpulan: Empat kali langkah piston atau dua kali putaran crankshaft, menghasilkan satu kali pembakaran.

2. Motor diesel 2 langkah

Motor diesel 2 langkah adalah motor diesel yang satu kali proses pembakarannya memerlukan dua langkah torak atau satu kali putaran poros engkol.
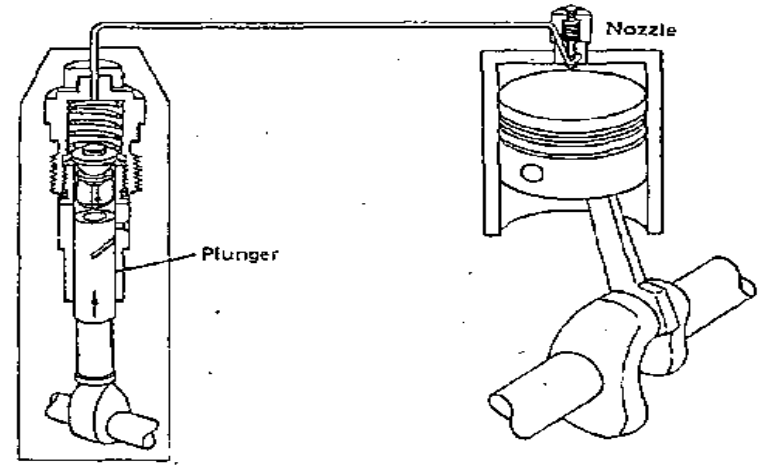

Gambar 2. Prinsip Kerja Motor Diesel 2 Langkah(Sumber gambar: mechanic development PT.Pama Persada Nusantara,2004)

a. Langkah Pembilasan dan Kompresi

Pada awal langkah ini udara masuk silinder melalui lubang masuk pembilasan (port scavenging) yang terdapat di bagian bawah silinder. Lubang ini akan terbuka saat torak bergerak ke bagian bawah mendekati TMB (titik mati bawah) dan akan tertutup saat torak bergerak keatas meninggalkan TMB.

Pada saat lubang pembilasan tertutup oleh torak yang bergerak keatas menuju TMA (titik mati atas) dan katup buang juga tertutup maka di mulailah proses kompresi. Gerakan torak ke atas akan menyebabkan tekanan udara dalam silinder meningkat seiring dengan peningkatan temperatur udara. Dan beberapa derajat sebelum torak mencapai TMA bahan bakar mulai disemprotkan kedalam silinder (dikabutkan) oleh injektor, karena temperatur di dalam silinder sangat tinggi sehingga bahan bakar yang dikabutkan tersebut akan terbakar (Hermawan, 2011).

Proses pembakaran ini akan menyebabkan kenaikan tekanan dan temperatur secara drastis, tekanan dan temperatur maksimal akan terjadi beberapa saat setelah torak mulai bergerak ke bawah. Gas bertekanan tinggi ini akan mendorong torak bergerak ke bawah dan melalui batang torak akan memutar poros engkol yang akan menghasilkan energi putaran.

b. Langkah Ekspansi dan Buang

Langkah ekspansi dan buang dimulai setelah terjadinya tekanan maksimum di dalam silinder akibat terbakarnya campuran bahan bakar dengan udara. Posisi torak bergerak menuju TMB (titik mati bawah).

Setelah terjadi tekanan maksimum di dalam silinder, torak akan terdorong menuju TMB dan katup buang mulai terbuka yang mengakibatkan perbedaan tekanan didalam silinder lebih besar daripada diluar silinder yang akan membuat gas sisa pembakaran keluar silinder serta gas sisa pembakaran keluar akibat terdesak oleh udara segar yang dimasukkan dengan paksa melalui lubang pembilasan dengan blower pembilas 
(turbocharger). Pada saat katup buang sudah tertutup proses pemasukan udara masih berlangsung untuk beberapa saat dengan bantuan kompressor pembilas sampai lubang pembilasan tertutup oleh torak, hal ini dimaksudkan untuk meningkatkan kapasitas volume dan menaikkan tekanan udara pembilas didalam silinder.

Demikian proses ini berlangsung secara terus menerus secara berkesinambungan. Dari dua kali gerakan naik turun torak menghasilkan satu kali langkah usaha, oleh karena itu disebut operasi dua langkah.

Pada desarnya prinsip kerja engine 2 langkah dan 4 langkah adalah sama,yakni: pengisapan,kompresi,kerja,dan

pembuangan. Sedangkan perbedaannya adalah pada jumlah putaran poros engkol per siklus yang menghasilkan kerja.

\section{Perhitungan Daya Engine}

Daya adalah kemampuan melakukan suatu usaha atau kerja dalam setiap satuan waktu tertentu.Daya mekanik suatu engine diawali oleh gerak lurus piston dari TMA ke TMB selama langkah usaha dengan perantara connecting rod dirubah menjadi gerak putar crankpin pada crankshaft.

Pengertian dasar dari pembakaran adalah reaksi kimia suatu zat dengan udara.Didalam engine yang berperan sebagai zat adalah bahan bakar.Reaksi ini menghasilkan beberapa senyawa kimia yang berupa berupa gas serta sejumlah panas atau kalor.Secara sederhana dapat dijelaskan sebagai berikut :

Bahan Bakar + Udara $\rightarrow \quad$ Gasgas $+\mathrm{x}$ Kcal

Panas hasil pembakaran ini diserap oleh semua bagian engine yang membentuk ruang bakar, termasuk dinding bagian dalam dari silinder serta oleh gas hasil pembakaran itu sendiri. Dengan demikian maka suhu gas akan meningkat dan mencapai puncaknya pada saat bahan bakar telah terbakar, yaitu saat torak berada pada posisi tertentu setelah TMA dan memasuki langkah usaha.

Dari hukum Boyle - Gay Lussac, kita ketahui bahwa:

$\frac{\mathrm{P}_{1} \times \mathrm{V}_{1}}{\mathrm{~T}_{1}}=\mathrm{C}$ atau $\frac{\mathrm{P}_{1} \times \mathrm{V}_{1}}{\mathrm{~T}_{1}}(1)$

Dimana:

$$
\begin{aligned}
& \mathrm{C}=\text { konstanta } \\
& \mathrm{T}=\text { Temperatur } \\
& \mathrm{P}=\text { Tekanan } \\
& \mathrm{V}=\text { Volume }
\end{aligned}
$$

Karena puncak pembakaran pada posisi tertentu dari torak, maka $\mathrm{V}_{1}=\mathrm{V}_{2}$ Jadi kita dapatkan:

$\frac{\mathrm{P}_{1}}{\mathrm{~T}_{1}}=\frac{\mathrm{P}_{2}}{\mathrm{~T}_{2}}(2)$

Berarti dengan meningkatnya suhu $\mathrm{T}_{2}$, maka tekanan gas $\mathrm{P}_{2}$ juga akan meningkat.Tekanan ini bekerja pada permukaan atas torak sepanjang langkah usaha, yaitu dari TMA ke TMB dengan penurunan nilai karena ekspansi gas yang mengikuti pembesaran volume sesuai dengan posisi torak. Didalam perhitungan yang digunakan adalah tekanan rata - rata didalam silinder selama langkah usaha tersebut. Tekanan ini disebut Tekanan Indikator Engine, sedangkan daya yang dihasilkan berdasarkan tekanan ini disebut sebagai Daya Indikator Engine. Maka daya indikator engine tersebut:

$$
\mathrm{I} \mathrm{HP}=\frac{\pi / 4 \times \mathrm{D}^{2} \times \mathrm{P} \times \mathrm{S} \times \mathrm{i} \times \mathrm{n}}{2 \times 60 \times 550}
$$

Sebagian dari daya indikator engine dipakai untuk menggerakkan komponen atau mekanisme dari sistem yang ada didalam engine itu sendiri. Sebagian lagi terpakai untuk mengatasi gesekan dan perlawanan selama langkah kompresi. Semua ini dinyatakan sebagai kerugian mekanis. Dengan adanya kerugian ini, maka tekanan rata-rata yang berguna menjadi berkurang. Tekanan akhir ini disebut sebagai tekanan efektif atau brake mean effective pressure (BMEP). Nilai BMEP ini ada didalam data spesifikasi 
engine. Dengan menggunakan BMEP, kita dapat menghitung daya efektif engine yaitu daya yang diukur pada flywheel. Daya efektif engine ini disebut juga brake horse power (BHP). Jadi:

$\mathrm{BHP}=\frac{\pi / 4 \times \mathrm{D}^{2} \times \mathrm{BMEP} \times \mathrm{S} \times \mathrm{i} \times \mathrm{n}}{2 \times 60 \times 550}$

Dimana:

$\mathrm{BHP}=$ daya engine $(\mathrm{HP})$

$\mathrm{BMEP}=$ Tekanan efektif terhadap piston (psi)

$\mathrm{D}=$ Diameter piston (inchi)

$\mathrm{S} \quad=$ Langkah piston $(\mathrm{ft})$

$\mathrm{i} \quad=$ Jumlah silinder

$\mathrm{n} \quad=$ Putaran engine (rpm)

Hubungan antara usaha piston dan crankpinengine dijelaskan sebagai berikut:
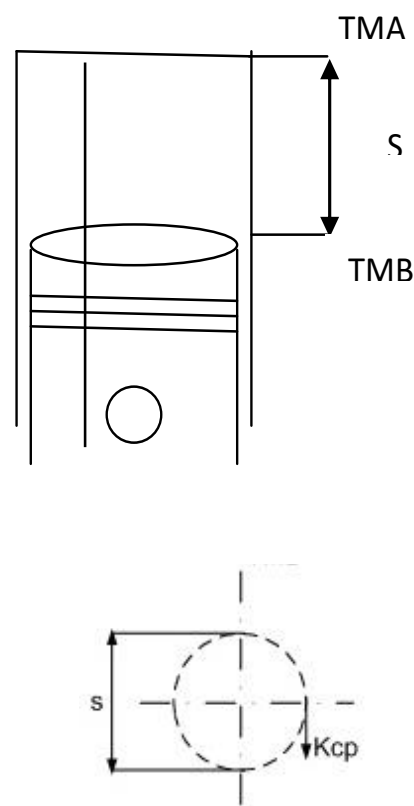

Gambar 3. SkemaLangkah PistonDan Crankpin.(Sumber Gambar: Cummins handbook)

Keterangan gambar :

$\mathrm{S}=$ Langkah piston

$\mathrm{Kp} \quad=$ Gaya linier piston

$\mathrm{Kcp} \quad=$ Gaya putar crankshaft

TMA = Titik mati atas

TMB = Titik mati bawah

Diameter lingkaran yang dilalui oleh crankpin sama dengan langkah piston dari TMA ke TMB.

\section{Pada Piston}

Dapat kita rumuskan usaha efektif total torak rata-rata dalam setiap putaran engineadalah:

$\mathrm{Wp}=\frac{\mathrm{Kp} \times \mathrm{S} \times \mathrm{i}}{2}=\frac{\pi / 4 \times \mathrm{D}^{2} \times \mathrm{BMEP} \times \mathrm{S} \times \mathrm{i}}{2}$

Dimana:

$\mathrm{Wp}=$ usaha efektif total torak (lbft)

$\mathrm{Kp}=$ tekanan terhadap torak (Psi)

\section{Pada Crankpin}

Besarnya torsi yang terjadi adalah:

$\mathrm{Tq}=\mathrm{Kcp} \times 1 / 2 \mathrm{~S}$

Dimana:

$\mathrm{Tq}=$ torsi (Lb.Ft)

Kcp = Gaya putar Crankpin/Crankshaft .

Usaha rata-rata dalam setiap putaran engine:

Wcp $=\operatorname{Kcp} \times \pi S=2 \pi(\operatorname{Kcp} \times 1 / 2 S)=2$

$\pi \times \mathrm{Tq}$

Dimana:

Wcp = usaha efektif pada crankpin (lb.ft)

Didalam sebuah engine, tentu saja berlaku Usaha Efektif Total Pistonsama dengan Usaha Total crankpin.

Jadi : Wp $=\mathrm{Wcp}$

Atau $: \frac{\pi / 4 \times D^{2} \times \text { BMEP x S x i }}{2}=2 \pi \times \mathrm{Tq}$

Karena :

$$
\begin{aligned}
& \mathrm{BHP}=\frac{\pi / 4 \times \mathrm{D}^{2} \times \text { BMEP } \times \mathrm{S} \times \mathrm{i} \times \mathrm{n}}{2 \times 60 \times 550} \\
& =\frac{\pi / 4 \times \mathrm{D}^{2} \times \mathrm{BMEP} \times \mathrm{S} \times \mathrm{i}}{2} \times \frac{\mathrm{n}}{60 \times 550}
\end{aligned}
$$

$\mathrm{BHP}=2 \pi \times \mathrm{Tq} \times \frac{\mathrm{n}}{60 \times 550}$

$\mathrm{BHP}=\frac{2 \pi \times \mathrm{Tq} \times \mathrm{n}}{60 \times 550}$

$\mathrm{BHP}=\frac{2 \times 3,1416}{60 \times 550} \times \mathrm{Tq} \times \mathrm{n}$ $=0,0001904 \times \mathrm{Tq} \times \mathrm{n}$

$\mathrm{BHP}=\frac{\mathrm{Tq} \times \mathrm{RPM}}{5252}$ 


\section{METODE PENELITIAN}

Adapun objek penelitian pada penulisan Penelitian ini di fokuskan pada Engine Cummins KTTA 38 C, Cummins menberikan nama engine KTTA $38 \mathrm{C}$ yang berarti :

- $\mathrm{K}$ adalah tipe atau family dari engine seri $\mathrm{K}$

- TTA adalah sistem pemasukan udara ke dalam ruang bakar yaitu double stage Turbocharger Aftercooler.

- 38 adalah total displacement dalam satuan liter.

Tampilan daripada Engine Diesel Cummins KTTA $38 C$ adalah sebagai berikut:

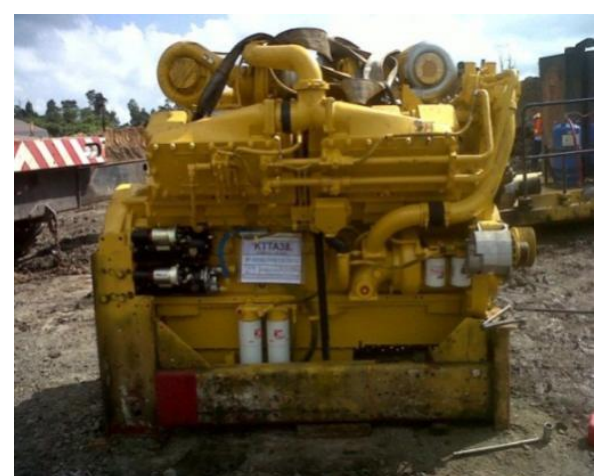

Gambar 4.Engine Diesel Cummins KTTA 38 C

Spesifikasi engine Cummins KTTA $38 \mathrm{C}$ adalah sebagai berikut:

a. Total Displacement: 37.7 Liter (2301 C.I.D)

b. Number Of Cylinder: V12

c. Bore and Stroke: $159 \mathrm{~mm}(6,25 \mathrm{in}) \mathrm{x}$ $159 \mathrm{~mm}(6,25 \mathrm{in})$

d. Compression Ratio: $15,0: 1$

e. Engine Power: 1260 HP @ 1800 RPM

f. Peak Torque: 3767 Lbft @ 1400 RPM

g. Low Idle Speed: $700 \pm 25$ RPM

h. High Idle Speed: 1900 RPM

i. Oil Pressure Idle: $138 \mathrm{kPa}$ (20 psi)

j. Oil Pressure rated: $310 \mathrm{kPa}(45 \mathrm{psi})-$ $483 \mathrm{kPa}(70 \mathrm{psi})$

k. Boost Pressure: 38 - 55 inhg

1. Coolant Temperature: $72-94{ }^{\circ} \mathrm{C}$

\section{Alat Dan Bahan Penelitian}

1. Taylor Dynamometer DS4010
Dinamometer atau dynotest, adalah sebuah alat yang digunakan mengukur daya dan torsi yang di hasilkan dari suatu alat yang berputar dalam hal ini alat yang dimaksud adalah engine.

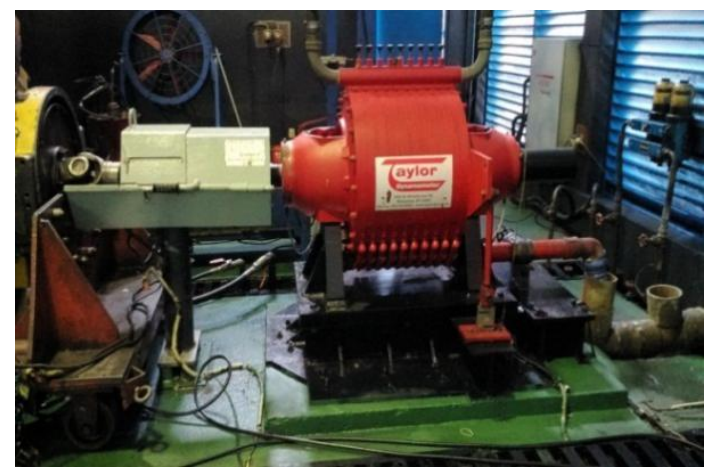

Gambar 5. Taylor Dynamometer DS4010 (Dokumentasi Oktober 2015)

Adapun spesifikasi dari Taylor Dynamometer DS4010:

a. Power: $3.500 \mathrm{HP}(2.611 \mathrm{kw})$

b. Torque: 11.263 Lb.ft $(15.271 \mathrm{Nm})$

c. Speed: $2.800 \mathrm{RPM}$

d. Water Use: 255 GPM $(16,1 \mathrm{~L} / \mathrm{s})$

e. Shipping Weight: $4.620 \mathrm{lbs}(2.097$ $\mathrm{kg}$ )

f. Accessories: Drive Shaft, Adapter Plate Kit, Shaft Guard, Air Stater Single or Dual Directioanal, Base Kit, Throttle Control, Water Recticulating System, Engine Cart, Closed Loop Cooling System.

2. Instrumen Sensor

\section{Langkah Penelitian}

1. Melakukan engine,langkah yang dilakukan sebagai berikut:

a. Memasang engine di stand dynotest room

b. Memasang / menyambungkan engine dengan dynamometer

c. Memasang instrumen sensor diantaranya :

1) Coolant temperature and pressure

2) Oil temperature and pressure

3) Piston cooling oil pressure

4) Air inlet restriction

5) Intake manifold temperature and pressure 
6) Fuel rail pressure

7) Fuel restriction and temperature

8) Exhaust temperature and restriction

d. Menyambungkan peralatan ke engine diantaranya:

1) Air inlet piping

2) Exhaust piping

3) Electric harness for command ECM (electronic control module)

4) Battery cables or air supply

5) Fuel inlet and outlet to engine

6) Coolant engine inlet and outlet piping

7) Coolant LTA (Low Temperature Aftercooler) inlet and outlet piping.

e. Mengetes kebocoran pada sistem pelumas,pendingin,udara, bahan bakar

f. Mengetes priming pump pada sistem pelumasan.

2. Mengoperasikan engine untuk tes performansi.

3. Melakukan penelitian / analisa saat engine beroperasi.

4. Mendapatkan data hasil pengujian dalam bentuk tabel.

\section{Diagram Alir Penelitian}

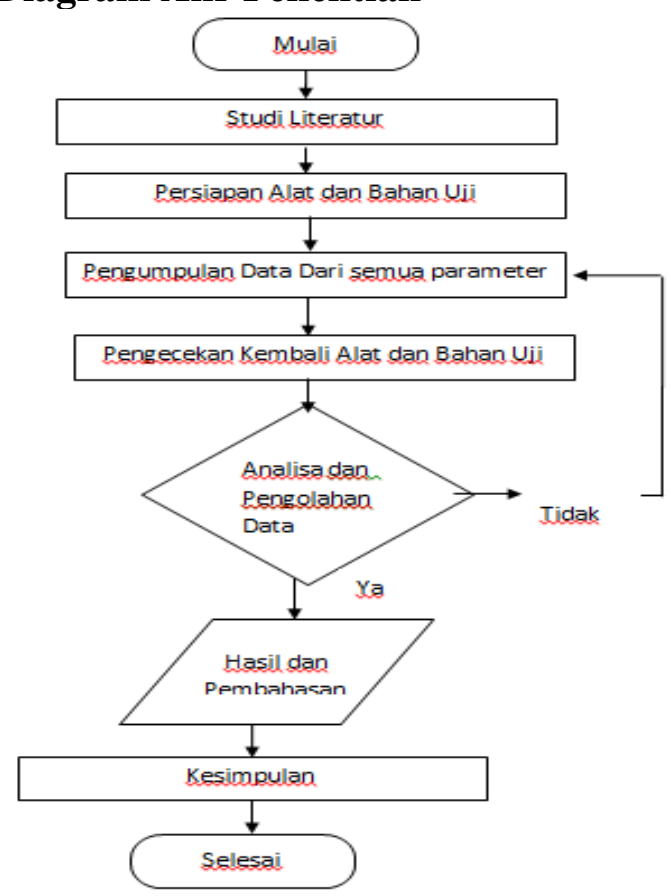

Gambar 6. Diagram Alir Penelitian

\section{HASIL DAN PEMBAHASAN}

Penelitian dilaksanakan di PT.Altrak 1978, hasil dynotest yang menggunakan alat Dynamometer Taylor yang dipasang pada bagian flywheel engine pada engine Cummins KTTA 38C memberikan gambaran nyata performansinya setelah dilakukan overhaul pada 12.000 jam kerja. Semua hasil parameterengine yang di peroleh dari pengukuran dynotest seperti yang ditunjukan pada Tabel 1 setelah dilakukan pengklasifikasian.

Tabel 1. Data Hasil Dynotest

\begin{tabular}{|l|l|l|l|l|l|l|}
\hline No. & Parameter & Hasil 1 & Hasil 2 & Hasil 3 & Hasil 4 & Hasil 5 \\
\hline 1. & $\begin{array}{l}\text { Engine speed } \\
\text { (Rpm) }\end{array}$ & 1501.583 & 1603.29 & 1706.614 & 1801.587 & 1910.096 \\
\hline 2. & Power (HP) & 1096.496 & 1178.389 & 1253.142 & 1324.583 & 46.759 \\
\hline 3. & Torque (lbs/ft) & 3833.263 & 3860.19 & 3855.934 & 3862.313 & 128.122 \\
\hline 4. & $\begin{array}{l}\text { Boost pressure } \\
\text { RB (in Hg) }\end{array}$ & 50.478 & 54.801 & 57.954 & 60.947 & 4.671 \\
\hline 5. & $\begin{array}{l}\text { Boost pressure } \\
\text { LB (in Hg) }\end{array}$ & 51.985 & 56.705 & 60.123 & 63.379 & 5.463 \\
\hline 6. & $\begin{array}{l}\text { Oil pres sure } \\
\text { (Psi) }\end{array}$ & 73.949 & 77.138 & 79.168 & 81.093 & 86.782 \\
\hline 7. & $\begin{array}{l}\text { Temp.exhaust } \\
\text { RB (deg C) }\end{array}$ & 436.361 & 415.423 & 400.667 & 396.164 & 274.006 \\
\hline 8. & $\begin{array}{l}\text { Temp.exhaust } \\
\text { LB (Deg C) }\end{array}$ & 380.174 & 369.356 & 362.12 & 356.81 & 258.776 \\
\hline 9. & $\begin{array}{l}\text { Temp. coolant } \\
\text { (Deg C) }\end{array}$ & 79.684 & 79.667 & 79.349 & 78.255 & 51.254 \\
\hline 10. & $\begin{array}{l}\text { Coolant } \\
\text { pressure (Psi) }\end{array}$ & 15.932 & 17.427 & 19.087 & 21.081 & 24.159 \\
\hline 11. & $\begin{array}{l}\text { Fuel pres sure } \\
\text { (Psi) }\end{array}$ & 98.702 & 108.231 & 117.495 & 127.279 & 7.526 \\
\hline
\end{tabular}

Setelah didapatkan hasil penelitian dengan menggunakan alat uji dynotest padaengine Cummins KTTA $38 \mathrm{C}$ setelah dilakukan overhaul12000 jam. Hasil yang terbaik dari engine tersebut adalah dapat mencapai daya maksimum sebesar 1324.583 HP pada putaran engine $1801.587 \mathrm{rpm}$. Untuk dapat mengetahui hubungan antara daya dengan putaran mesin maka akan dilakukan perhitungan yang mana akan menampilkan keterkaitan antara daya, torsi dan putaran mesin. Dalam menghitung daya terhadap putaran mesin maka di gunakan persamaan 8 data 
hasil dynotest sangat dibutuhkan untuk membantu dalam perhitungannya mencari daya engine dikarenakan hanya data dari alat uji yang benar - benar dianggap data yang akurat untuk dimasukan dalam perhitungan karena didapat langsung dari bahan yang diuji yaitu dalam kondisi sesuai yang diinginkan oleh peneliti.

Berikut perhitungan daya pada hasil 1 yang merujuk pada persamaan 8 pada untuk selanjutnya akan di rangkum dalam tabel,

Hasil 1 pada putaran engine 1501,583 rpm menghasilkan Torsi 3833,263 lbs/ft di dapatkan hasil :

$$
\begin{aligned}
\text { BHP } & =\frac{\text { Torsi } x \text { RPM }}{5252} \\
& =\frac{3833.263 \times 1501.583}{5252} \\
& =\frac{5755962.6}{5252} \\
& =1095.9563 \mathrm{HP}
\end{aligned}
$$

Dari analisa pengaruh variasi putaran mesin terhadap daya yang melakukan pengukuran langsung pada engine cummins KTTA $38 \mathrm{C}$ dengan menggunakan alat uji dynotest dan hasil dengan perhitungan teoritis terhadap variasi putaran mesin terhadap daya pada enggine. Maka akan dilakukan perbandingan antara hasil pengukuran langsung dengan alat uji dynotest dan hasil perhitungan teoritis, yang mana akan menjelaskan pengaruh variasi putaran mesin terhadap daya dan akan membuktikan juga kebenaran daripada persamaan 8 pada untuk melakukan perhitungan daya. Hasil teoritis perhitungan daya dirangkum dalam tabel 2 dan Hasil pengukuran daya dengan Dynotest di rangkum pada tabel 3.

Tabel 2. Hasil Teoritis Perhitungan Daya

\begin{tabular}{ccc}
\hline No & $\begin{array}{c}\text { Putaran Mesin } \\
(\mathrm{Rpm})\end{array}$ & $\begin{array}{c}\text { Daya Hasil } \\
\text { Perhitungan (HP) }\end{array}$ \\
\hline 1 & 1501.583 & 1095.956313 \\
\hline 2 & 1603.29 & 1178.408992 \\
\hline 3 & 1706.614 & 1252.968573 \\
\hline
\end{tabular}

\begin{tabular}{lll}
\hline 4 & 1801.587 & 1324.884404 \\
\hline 5 & 1910.096 & 46.59659553 \\
\hline
\end{tabular}

Dari tabel 2 dapat ditampilkan dalam bentuk grafik pada gambar 5 sehingga dapat dilihat pengaruh putaran mesin terhadap daya menurut hasil perhitungan yang telah dilakukan, pada grafik putaran engine terhadap daya akan menjelaskan garis gaya yang terjadi mulai pada putaran engine $1500 \mathrm{rpm}$ sampai pada putaran $1900 \mathrm{rpm}$.

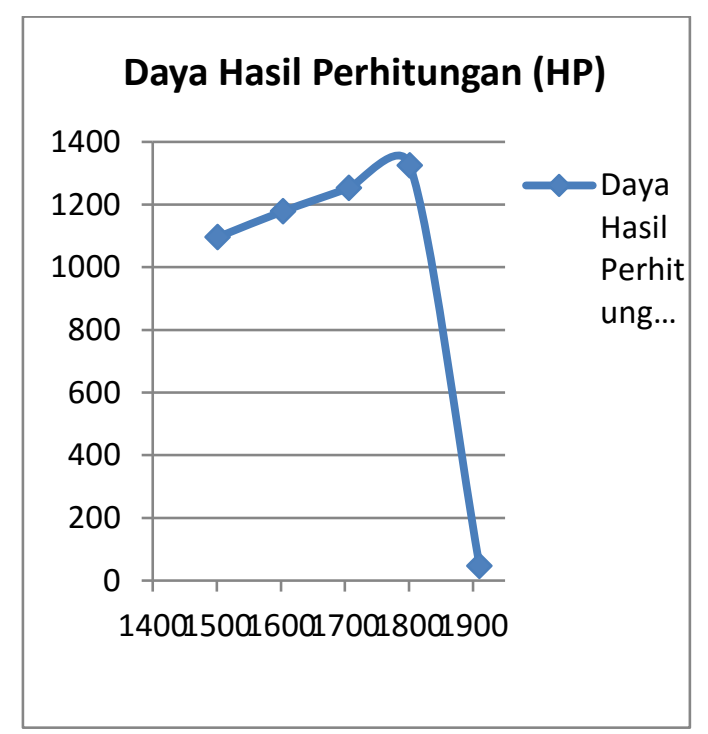

Gambar 7. Daya Hasil Perhitungan

Tabel 3. Daya Hasil Dynotest

\begin{tabular}{ccc}
\hline No & $\begin{array}{c}\text { Putaran } \\
\text { Mesin } \\
(\mathrm{Rpm})\end{array}$ & $\begin{array}{c}\text { Daya Hasil } \\
\text { Dynotest } \\
(\mathrm{HP})\end{array}$ \\
\hline 1 & 1501.583 & 1096.496 \\
\hline 2 & 1603.29 & 1178.389 \\
\hline 3 & 1706.614 & 1253.142 \\
\hline 4 & 1801.587 & 1324.583 \\
\hline 5 & 1910.096 & 46.759 \\
\hline
\end{tabular}

Dari tabel 3 dapat ditampilkan pula dalam bentuk grafik pada gambar 7 sehingga dapat dilihat pengaruh putaran mesin terhadap daya menurut hasil alat uji dynotest, pada grafik putaran engine terhadap daya akan menjelaskan garis 
gaya yang terjadi mulai pada putaran engine $1500 \mathrm{rpm}$ sampai pada putaran $1900 \mathrm{rpm}$.

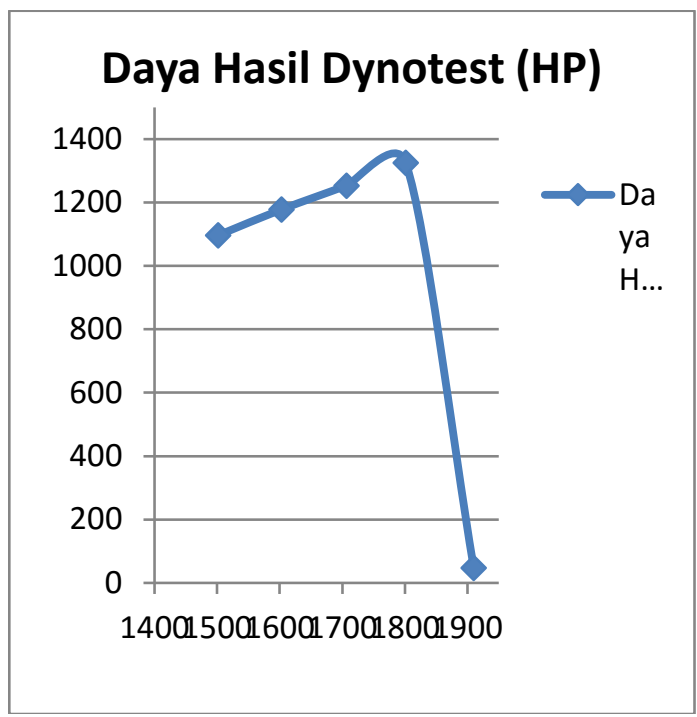

Gambar 7. Daya Hasil Dynotest

Dari kedua gambar pada gambar 6 dan gambar 7 yang menunjukan grafik putaran engine terhadap daya. Garis daya engine sama - sama membentuk garis yang mulai menanjak pada putaran 1500 rpm dengan daya berkisar 1096 HP hingga pada puncaknya pada putaran 1800 rpm menghasilkan daya sebesar 1324 HP dan sama - sama menurun tajam pada putaran $1910 \mathrm{rpm}$ dengan besar daya yang sama 46 HP. Selisih nilai dari kedua grafik yang ditampilkan adalah sangat kecil sehingga membentuk garis daya yang sama pula dan dapat disimpulkan atau dianggap sama.

\section{SIMPULAN DAN SARAN \\ Simpulan}

Pengaruh putaran Engine cummins KTTA $38 \mathrm{C}$ terhadap daya adalah tiap perubahan putaran engine yang terjadi dapat mempengaruhi nilai daya yang di hasilkan oleh engine itu sendiri. Semakin tingginya putaran engine terhadap beban maka akan semakin banyak juga pembakaran yang terjadi didalam ruang bakar sehingga akan menghasilkan tenaga daripada engine itu sendiri.

\section{Saran}

Selalu melakukan perawatan berkala terhadap engine sesuai dengan jadwal yang ditentukan, kritis terhadap masalah mulai dari masalah kecil sampai masalah besar yang timbul pada engine dan segera lakukan perbaikan, melakukan general overhaul sesuai dengan jadwal yang ditentukan. Hal tersebut sangat dibutuhkan untuk selalu menjaga dan meningkatkan performansi engine yang turun akibat pengoperasian engine tersebut.

\section{DAFTAR PUSTAKA}

Clark, A. (1998). Shop Manual Cummins K38 And K50 Series Engine, Cummins Inc.

Daryanto. (2004). Motor Diesel Pada Mobil. Yrama Widya, Bandung.

Fernandez, D. (2009). Pengaruh Putaran Mesin Terhadap Emisi Gas Buang Hidrokarbon (HC) dan Karbon Monoksida (CO). Sainstek, 12(1), 81-84.

Hermawan, Bambang. (2011). Training Module Intensive Mechanic Course, Altrak 1978, Jakarta.

Mechanic development PT.Pama Persada Nusantara, 2004, Motor diesel, Jakarta.

Permana, Danu, (2005). Merawat \& Memperbaiki Mobil Diesel. Puspa Swara: Jakarta.

Purnama, S., \& Saksono, P. (2015). Analisa Perbandingan Aplikasi Sistem Satu dan Dua Tingkat Turbocaharger Terhadap Performansi Cummins Engine K38C. JTT (Jurnal Teknologi Terpadu), 3(1). 